\title{
Infeksi Influenza A dan B pada Anak dengan Influenza Like IIIness [ILI] atau Pneumonia di Jakarta
}

\author{
Wahyuni Indawati, Darmawan B Setyanto, Nastiti Kaswandani \\ Departemen Ilmu Kesehatan Anak Fakultas Kedokteran Universitas Indonesia/RS Dr. Cipto \\ Mangunkusumo, Jakarta
}

\begin{abstract}
Latar belakang Secara global, influenza merupakan salah satu penyebab utama morbiditas dan mortalitas pada anak serta menimbulkan beban ekonomi yang cukup besar. Manifestasi infeksi ini secara klinis sulit dibedakan dengan penyebab lain pada pasien dengan Influenza Like Illness (ILI) atau pneumonia.

Tujuan. Menilai proporsi infeksi influenza A dan B pada anak dengan ILI dan pneumonia, mengetahui karakteristik subjek dengan infeksi influenza serta faktor yang memengaruhinya.

Metode. Penelitian potong lintang dilakukan di RS Cipto Mangunkusumo dan Puskesmas Kecamatan Pulo Gadung sejak Januari 2010 hingga Oktober 2010. Pada anak berusia 0-14 tahun dengan diagnosis ILI atau pneumonia sesuai kriteria WHO dilakukan rapid test untuk influenza dengan menggunakan bahan usapan nasofaring. Data karakteristik klinis, demografi, dan lingkungan dicatat dalam formulir penelitian.

Hasil. Didapatkan proporsi infeksi influenza A dan B pada anak dengan ILI dan pneumonia 14/167 (8,3\%). Sebagian besar menderita infeksi influenza B (12/14 subjek). Usia $>5$ tahun berhubungan dengan kejadian infeksi influenza yang lebih tinggi dibandingkan kelompok usia $\leq 5$ tahun $(p=0,012)$. Selain demam, gejala lain berupa batuk, sakit kepala, nyeri otot, lesu, dan nyeri tenggorok lebih banyak didapatkan pada subjek dengan infeksi influenza.

Kesimpulan. Pada anak dengan ILI dan pneumonia, proporsi infeksi influenza 8,3\%, terutama didapatkan infeksi Influenza B. Usia merupakan faktor yang memengaruhi infeksi influenza. Karakterustik klinis subjek dengan infeksi influenza sesuai dengan manifestasi klasik penyakit tersebut. Sari Pediatri 2014;16(2):136-42.
\end{abstract}

Kata kunci: influenza A, influenza B, anak, ILI, pneumonia, rapid test

I

nfeksi respiratorik akut (IRA) merupakan penyakit yang paling sering dijumpai. Di dunia, IRA merupakan penyebab utama penyakit akut yang mengakibatkan kematian 2 juta jiwa bayi dan anak

Alamat korespondensi:

Dr. Wahyuni Indawati, Sp.A. Divisi Respirologi. Departemen Ilmu Kesehatan Anak. Jalan Salemba no. 6, Jakarta 10430. Telp. (021)

3148930. Fax.: (021) 3148931. Email: wahyuniindawati@yahoo.com setiap tahun. ${ }^{1,2}$ Pada anak, mikroorganisme penyebab utama IRA di antaranya Streptococcus pneumoniae, Haemophilus influenzae type b (Hib), Staphylococcus aureus, dan beberapa spesies bakteri lainnya, respiratory syncytial virus (RSV), virus campak, virus Human Parainfluenza type 1, 2, dan 3 (PIV-1, PIV-2, dan PIV3), virus Influenza dan virus Varicella. ${ }^{3}$

Influenza merupakan penyebab utama morbiditas dan mortalitas serta menimbulkan beban ekonomi 
yang cukup besar. ${ }^{4}$ Secara global, diperkirakan terdapat 600 juta kasus, 3 juta kasus penyakit akut dan 250.000-500.000 jiwa meninggal setiap tahun akibat infeksi virus influenza musiman. ${ }^{5}$ Virus influenza dapat menyerang semua golongan usia, dengan angka infeksi tertinggi terutama terjadi pada anak yang masih sangat muda. Virus influenza menyebar melalui udara berupa percik renik dari saluran respiratorik orang yang terinfeksi, yang batuk, bersin, atau melalui kontak langsung dari tangan yang terkontaminasi oleh sekret respiratorik. Virus influenza bersifat sangat menular, dapat menyebabkan infeksi berulang, dan merupakan penyebab epidemik tahunan. ${ }^{6}$

Gejala sistemik utama infeksi influenza adalah demam, sakit kepala, nyeri otot, lemas, batuk, dan nyeri menelan. Selama puncak masa influenza, diperkirakan lebih dari 70\% ILI disebabkan oleh virus influenza. Meskipun demikian, pasien yang terinfeksi oleh virus respiratorik lainnya dan sering bersirkulasi bersamaan dengan sirkulasi virus influenza pada suatu komunitas, seringkali menunjukkan gejala yang sama. ${ }^{7}$ Beberapa penelitian melaporkan bahwa diagnosis infeksi virus influenza berdasarkan gejala demam dan batuk dapat mencapai ketepatan $77 \%$ $87 \% .^{8-10}$ Membedakan virus influenza dengan virus respiratorik lainnya sangat penting karena penyakit yang disebabkannya berhubungan dengan tingkat morbiditas dan mortalitas yang lebih tinggi sehingga berpotensi untuk dicegah dan diobati dengan vaksin maupun obat antiviral spesifik. ${ }^{8}$

Penegakan diagnosis yang tepat untuk infeksi virus influenza memerlukan uji laboratorium dan interpretasi hasil uji yang akurat. Kultur virus merupakan baku emas untuk diagnosis influenza, tetapi membutuhkan waktu yang cukup lama untuk memperoleh hasil uji (2-14 hari) sehingga tidak praktis untuk pengambilan keputusan klinis. ${ }^{4}$ Reverse - transcription polymerase chain reaction (RT-PCR) merupakan metode pemeriksaan influenza yang lebih sensitif daripada kultur virus dan hasil uji dapat diperoleh dalam waktu beberapa jam. Meskipun demikian, RT-PCR jarang dipakai untuk keperluan klinis karena relatif mahal. ${ }^{11}$ Sebagai alternatif, uji cepat deteksi antigen influenza (rapid test) dapat digunakan untuk diagnosis karena relatif tidak mahal dan memberikan hasil atau informasi yang cepat untuk pengambilan keputusan klinis. ${ }^{12,13}$ Rapid test dapat membantu pengaturan pengobatan antiviral, kontrol transmisi infeksi nosokomial, dan berkontribusi dalam reduksi biaya dan lama rawat pasien di rumah sakit. ${ }^{14,15}$ Oleh karena itu, saat ini rapid test telah tersebar luas penggunaannya. Penelitian ini bertujuan untuk menilai proporsi kontribusi infeksi influenza $\mathrm{A}$ dan $\mathrm{B}$ pada anak dengan ILI dan pneumonia, mengetahui karakteristik subjek dengan infeksi influenza, serta faktor yang memengaruhinya.

\section{Metode}

Penelitian dengan desain potong lintang dilakukan di Rumah Sakit Cipto Mangunkusumo dan Puskesmas Kecamatan Pulo Gadung mulai Januari 2010 hingga Oktober 2010. Populasi penelitian adalah semua anak yang berusia 0-14 tahun yang datang ke klinik rawat jalan dan/atau pasien yang dirawat di bangsal rawat inap dengan ILI dan/atau pasien dengan pneumonia. Kriteria inklusi adalah anak yang didiagnosis mengalami ILI atau pneumonia sesuai kriteria WHO, berupa demam (suhu tubuh saat datang $>37,8^{\circ} \mathrm{C}$ ) dan batuk atau nyeri menelan serta dapat disertai pilek atau mialgia atau demam (suhu tubuh saat datang $>37,8^{\circ} \mathrm{C}$ ) dan batuk disertai nafas cepat (takipnea) sesuai usia dan/atau kesulitan bernapas (yang ditandai dengan adanya retraksi sela iga, suprasternal, subkosta, epigastrium, napas cuping hidung). Kriteria eksklusi adalah anak tersangka malaria, demam dengue atau demam berkepanjangan atau berulang, dan orangtua yang menolak anaknya untuk mengikuti penelitian. Penelitian ini telah mendapatkan persetujuan etik dari komite etik penelitian FKUI RSCM.

Semua subjek yang masuk dalam kriteria inklusi dan eksklusi mengikuti penelitian setelah dilakukan informed consent. Seluruh data demografis dan klinis yang relevan dengan penelitian akan dicatat dalam formulir penelitian. Data termasuk umur, jenis kelamin, anggota keluarga yang memiliki gejala yang sama, riwayat imunisasi, riwayat pemberian ASI, paparan asap rokok dan gejala yang terdapat pada subjek. Tingkat pendidikan orangtua subjek digolongkan menjadi rendah (tidak sekolah, SD, SMP), sedang (SMA atau yang sederajat) dan tinggi (akademi dan universitas). Spesimen usapan nasofaring akan dikumpulkan dari anak yang memiliki gejala penyakit serupa influenza. Rapid test akan dilakukan untuk mendeteksi adanya virus influenza A dan B. Sepuluh persen dari subjek dengan hasil negatif pada rapid test akan dilakukan konfirmasi ulang dengan RT-PCR. 
Penelitian ini menggunakan BinaxNow ${ }^{\circledR}$ Influenza $A \& B$ Test untuk mendeteksi virus influenza $A$ dan B. BinaxNow ${ }^{\circledR}$ Influenza $A$ \& $B$ Test adalah uji invitro imunokromatogenik yang dapat mendeteksi nukleoprotein dari antigen virus influenza $A$ dan $B$, baik dari usapan nasofaring, usapan hidung atau aspirasi/bilasan hidung. Hasil dapat dibaca dalam 15 menit setelah menaruh spesimen usapan pada sample pad. Hasil positif didapatkan apabila pada sample pad menunjukkan dua garis horizontal berwarna merah.

Analisis statistik dilakukan menggunakan program SPSS versi 16 (SPSS, Chicago, IL, USA). Data proporsi akan disajikan dalam bentuk sebaran frekuensi dan persentase. Perbandingan antara kelompok dengan hasil rapid test (positif/negatif) akan dianalisis dengan uji chi-square dan nilai $\mathrm{p}<0,05$ dianggap bermakna.

\section{Hasil}

Penelitian ini mendapatkan infeksi virus influenza pada $14(8,3 \%)$ dari 167 anak yang mengalami ILI atau pneumonia. Didapatkan 12 anak dengan hasil rapid test positif influenza B dan 2 anak dengan hasil rapid test positif influenza A. Sebagian besar subjek penelitian $(86,2 \%)$ berasal dari kunjungan Puskesmas dan hanya
Tabel 1. Sebaran subjek berdasarkan sosiodemografis dan keadaan lingkungan

\begin{tabular}{|c|c|}
\hline Variabel & $\mathrm{N}=167(\%)$ \\
\hline \multicolumn{2}{|l|}{ Jenis kelamin } \\
\hline Laki-laki & $95(56,9)$ \\
\hline Perempuan & $72(43,1)$ \\
\hline \multicolumn{2}{|l|}{ Usia (tahun) } \\
\hline $0-1$ & $33(19,8)$ \\
\hline $2-5$ & $72(43,1)$ \\
\hline $6-14$ & $61(36,5)$ \\
\hline \multicolumn{2}{|c|}{ Pendidikan orang tua } \\
\hline Rendah & $66(39,5)$ \\
\hline Sedang & $68(40,7)$ \\
\hline Tinggi & $18(10,8)$ \\
\hline \multicolumn{2}{|l|}{ Pemberian ASI } \\
\hline $\mathrm{Ya}$ & $88(52,7)$ \\
\hline Tidak & $78(46,7)$ \\
\hline \multicolumn{2}{|l|}{ Riwayat imunisasi } \\
\hline Lengkap & $125(74,8)$ \\
\hline Tidak lengkap & $42 \quad(25,2)$ \\
\hline \multicolumn{2}{|c|}{ Riwayat imunisasi influenza } \\
\hline Ya & $1 \quad(0,6)$ \\
\hline Tidak & $166(96,4)$ \\
\hline \multicolumn{2}{|c|}{ Paparan asap rokok } \\
\hline $\mathrm{Ya}$ & $111(66,5)$ \\
\hline \multirow{2}{*}{\multicolumn{2}{|c|}{ Penderita IRA atas lain di rumah }} \\
\hline & \\
\hline $\mathrm{Ya}$ & $79(47,3)$ \\
\hline Tidak & $88(52,7)$ \\
\hline
\end{tabular}

Tabel 2. Hubungan antara karakteristik subjek penelitian dengan infeksi influenza

\begin{tabular}{|c|c|c|c|}
\hline \multirow[t]{2}{*}{ Variabel } & \multicolumn{2}{|c|}{ Kelompok } & \multirow{2}{*}{$\mathrm{p}$} \\
\hline & $\begin{array}{l}\text { Positif } \\
(\mathrm{n}=14)\end{array}$ & $\begin{array}{l}\text { Negatif } \\
(\mathrm{n}=153)\end{array}$ & \\
\hline \multicolumn{4}{|l|}{ Jenis kelamin } \\
\hline Laki-laki & 8 & 87 & \multirow[t]{2}{*}{0,984} \\
\hline Perempuan & 6 & 66 & \\
\hline \multicolumn{4}{|l|}{ Usia (tahun) } \\
\hline $0-5$ & 4 & 101 & \multirow[t]{2}{*}{$0,012^{*}$} \\
\hline $6-14$ & 10 & 52 & \\
\hline \multicolumn{4}{|l|}{ Pemberian ASI } \\
\hline Ya & 8 & 80 & \multirow[t]{2}{*}{0,746} \\
\hline Tidak & 6 & 73 & \\
\hline \multicolumn{4}{|c|}{ Riwayat imunisasi dasar } \\
\hline Lengkap & 13 & 112 & \multirow[t]{2}{*}{0,191} \\
\hline Tidak lengkap & 1 & 41 & \\
\hline \multicolumn{4}{|c|}{ Riwayat imunisasi influenza } \\
\hline $\mathrm{Ya}$ & 0 & 1 & \multirow[t]{2}{*}{1,000} \\
\hline Tidak & 14 & 152 & \\
\hline \multicolumn{4}{|c|}{ Paparan asap rokok } \\
\hline $\mathrm{Ya}$ & 7 & 104 & \multirow[t]{2}{*}{0,236} \\
\hline Tidak & 7 & 49 & \\
\hline \multicolumn{4}{|c|}{ Penderita IRA atas lain di rumah } \\
\hline $\mathrm{Ya}$ & 4 & 75 & \multirow[t]{2}{*}{0,142} \\
\hline Tidak & 10 & 78 & \\
\hline
\end{tabular}


9,6\% subjek yang didiagnosis sebagai pneumonia. Infeksi influenza tidak didapatkan pada subjek dengan diagnosis pneumonia. Karakteristik subjek berdasarkan sosiodemografis dan keadaan lingkungan tertera pada Tabel 1. Subjek penelitian dengan usia $\leq 5$ tahun didapatkan 62,9\%. Sebagian besar subjek memiliki orangtua dengan tingkat pendidikan rendah-sedang (80\%). Hanya $73 \%$ subjek penelitian yang memiliki riwayat imunisasi dasar lengkap, bahkan hanya 1 pasien yang memiliki riwayat imunisasi influenza.

Tidak didapatkan hubungan antara jenis kelamin, dibandingkan dengan non-influenza, beberapa gejala yang lebih dominan ditemukan adalah nyeri otot ( $71,4 \%$ vs $21,6 \%)$, sakit kepala $(85,7 \%$ vs $44,4 \%)$, lesu $(85,7 \%$ vs $63,4 \%)$, dan nyeri tenggorok $(57,1 \%$ vs $30 \%$ ), sedangkan pilek lebih banyak didapatkan pada subjek yang tidak mengalami infeksi influenza $(84,3 \%$ vs $71,4 \%)$. Pada proporsi manifestasi sistemik gastrointestinal (mual, muntah, nyeri perut, asupan makan berkurang) antara subjek dengan infeksi influeza dan infeksi non influenza tidak didapatkan perbedaan yang cukup besar (Gambar 1).

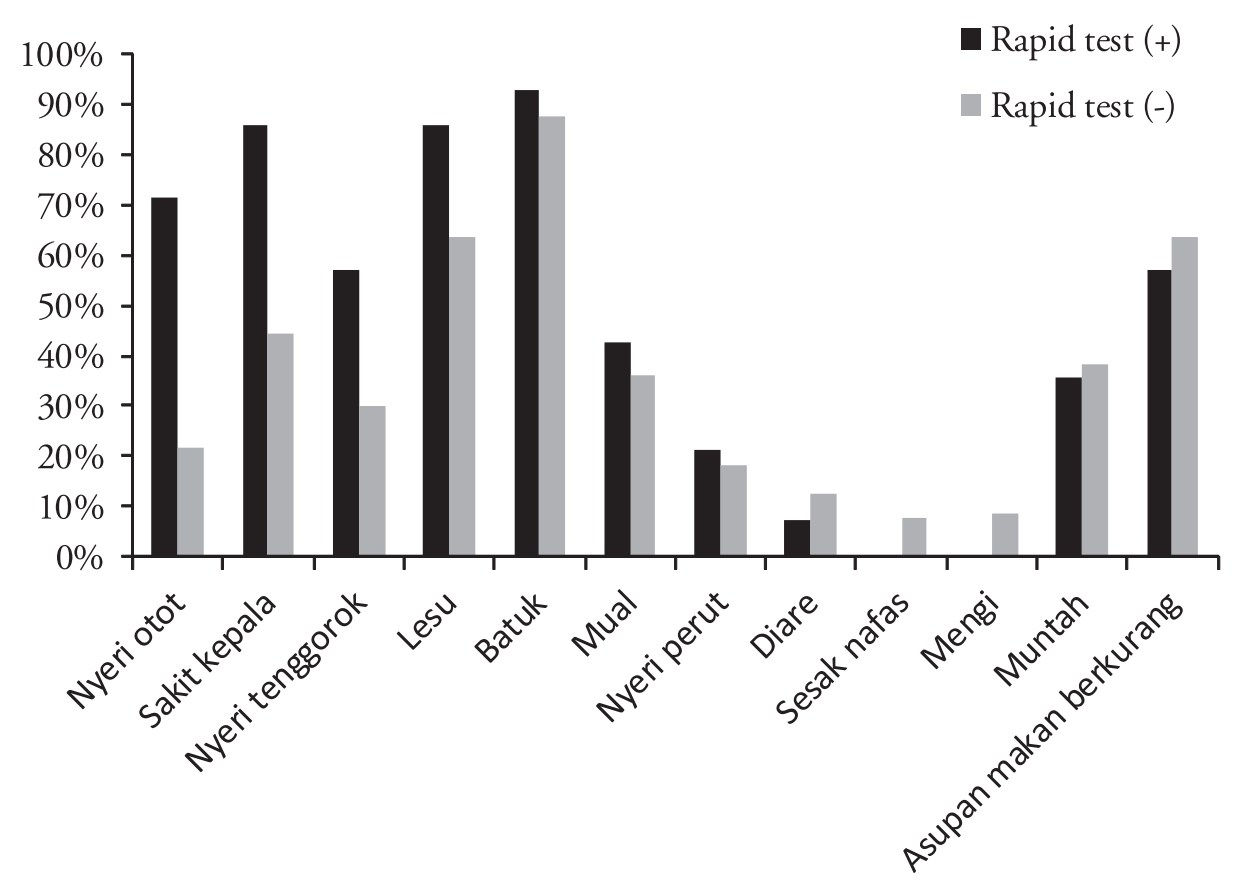

Gambar 1. Grafik sebaran karakteristik klinis pasien dengan infeksi influenza dan infeksi non influenza

pemberian ASI, riwayat imunisasi dasar, imunisasi influenza, paparan asap rokok dan anggota keluarga yang juga menderita IRA atas dengan proporsi infeksi influenza pada anak dengan ILI dan pneumonia. Usia subjek penelitian $>5$ tahun berhubungan dengan lebih tingginya angka kejadian infeksi influenza $(\mathrm{p}=0,012)$ (Tabel 2).

Manifestasi klinis batuk merupakan gejala yang paling sering ditemukan, baik pada subjek dengan infeksi influenza maupun infeksi non influenza $(92,8 \%$ vs $87,5 \%)$. Pada subjek dengan infeksi influenza

\section{Pembahasan}

Penelitian ini menggunakan rapid test sebagai metode diagnostik infeksi virus influenza. Sensitifitas dari rapid test berkisar antara 50\%-70\% jika dibandingkan dengan kultur virus atau RT-PCR dan spesifisitasnya berkisar antara 90\%-95\%. ${ }^{16}$ Metaanalisis terhadap penggunaan rapid test untuk deteksi infeksi influenza menunjukkan sensitifitas yang cukup baik, yaitu sekitar 70\% jika digunakan pada anak terutama pada usia $<5$ tahun, tetapi nilai sensitifitas ini akan sangat 
menurun hingga 30\% jika digunakan pada dewasa ataupun manula. ${ }^{17}$ Dengan demikian, pemeriksaan ini masih cukup relevan jika digunakan pada anak. Dalam penelitian ini, untuk mengonfirmasi kemungkinan negatif palsu dari hasil pemeriksaan rapid test, dilakukan pemeriksaan dengan $R T-P C R$ pada $10 \%$ (15) subjek secara acak dan didapatkan kesesuaian dengan hasil rapid test-nya.

Pada penelitian ini, proporsi infeksi influenza 8,3\%, lebih rendah jika dibandingkan dengan penelitian di Bali yang menunjukkan angka $12,2 \%$ (rapid test) dan $16,8 \%$ (RT-PCR). ${ }^{18}$ Beban penyakit yang disebabkan oleh infeksi influenza banyak dilaporkan terutama di Amerika, tetapi umumnya beban penyakit tersebut dihitung secara keseluruhan mencakup semua golongan umur sehingga menunjukkan angka yang sangat tinggi (sekitar 20\%, bahkan dapat mencapai $50 \%$ pada pertengahan musim dingin). ${ }^{19}$ Pada anak di Turki, penelitian kohort selama 20 tahun yang dilakukan pada rumah sakit tersier didapatkan infeksi influenza $4,4 \%(683 / 15429) .{ }^{20}$ Hasil yang sama $(4,3 \%)$ juga didapatkan pada anak yang dirawat di rumah sakit rujukan di Brazil yang dilakukan selama 5 tahun. ${ }^{21}$ Hasil yang bervariasi tentunya dipengaruhi oleh beberapa hal, di antaranya metode diagnostik yang digunakan, populasi penelitian, dan wilayah penelitian yang akan memengaruhi sirkulasi virus di daerah tersebut (negara 4 musim vs tropis).

Infeksi influenza B ditemukan lebih banyak dibandingkan infeksi influenza A (12/14). Di Bali, Purniti $\mathrm{dkk}^{18}$ juga mendapatkan hasil serupa (63/101). Hal tersebut berbeda dengan hasil yang didapatkan pada penelitian di Turki yang hanya mendapatkan 20\% infeksi influenza B dari keseluruhan kasus influenza pada anak. ${ }^{20}$ Lebih tingginya infeksi influenza $\mathrm{B}$ pada penelitian ini, disebabkan karena proporsi infeksi influenza lebih banyak didapatkan pada usia $>5$ tahun (10/14). Berbagai penelitian mendapatkan angka infeksi influenza $\mathrm{B}$ yang lebih tinggi dibandingkan influenza $\mathrm{A}$ pada anak usia sekolah..$^{20,21}$ Namun, penelitian di Bali dengan sebaran proporsi infeksi influenza berdasarkan usia yang relatif sama ( $\leq 5$ tahun $50,5 \%$ vs $>5$ tahun; $49,5 \%$ ), juga mendapatkan angka infeksi influenza B yang lebih tinggi. ${ }^{18}$ Dengan demikian, perlu ditelaah lebih lanjut dengan sistem surveilans apakah di Indonesia memang terdapat perbedaan distribusi serotipe influenza dengan negara lain.

Beberapa faktor risiko diketahui sebagai faktor predisposisi terjadinya IRA, antara lain usia, riwayat imunisasi, paparan asap rokok, adanya penderita IRA lain yang tinggal serumah, dan riwayat pemberian ASI. ${ }^{22,23}$ Penelitian ini dilakukan pada populasi yang yang menderita IRA (ILI atau pneumonia) sehingga dapat terlihat bahwa proporsi faktor risiko tersebut cukup tinggi ditemukan dalam karaktersitik subjek penelitian yaitu usia $\leq 5$ tahun $(63,5 \%)$, paparan asap rokok $(66,5 \%)$, cakupan imunisasi dasar hanya $75 \%$ dan hanya 1 subjek yang pernah mendapatkan vaksinasi influenza serta riwayat pemberian ASI hanya didapatkan pada 50\% subjek. Penelitian ini mencoba untuk menilai apakah faktor risiko ini berbeda pada subjek infeksi influenza dengan subjek infeksi non influenza. Hanya didapatkan variabel usia yang secara statistik berhubungan dengan infeksi influenza $(\mathrm{p}=0,012)$. Usia $>5$ tahun berhubungan dengan proporsi infeksi influenza yang lebih tinggi (10/52 vs 4/101). Hal tersebut dapat berhubungan dengan infeksi influenza $B(12 / 14)$ yang lebih tinggi dibandingkan influenza $A$ yang didapatkan pada penelitian ini sehingga proporsi infeksi influenza lebih banyak ditemukan pada anak dengan usia sekolah.

Berbagai penelitian mendeskripsikan gejala klasik infeksi influenza, yaitu demam, batuk, nyeri tenggorok, sakit kepala, lesu dan nyeri otot. ${ }^{20,21,24}$ Penelitian lain mendapatkan batuk dan demam sebagai prediktor klinis yang cukup baik (PPV 79\%) untuk mendiagnosis infeksi influenza. ${ }^{24}$ Penelitian ini mendapatkan batuk sebagai gejala tersering dan lebih banyak didapatkan pada subjek dengan infeksi influenza $(92,8 \%$ vs $87,5 \%)$. Manifestasi klinis sesuai gejala klasik influenza juga lebih banyak ditemukan pada subjek dengan hasil rapid test positif. Tidak didapatkan perbedaan yang cukup besar pada proporsi manifestasi sistemik non spesifik gastrointestinal antara subjek infeksi influenza dan infeksi non influenza. Hal tersebut disebabkan karena proporsi infeksi influenza pada usia $<5$ tahun tidak terlalu tinggi (4/101), padahal manifestasi non spesifik gastroinestinal yang disebabkan infeksi influenza umumnya didapatkan pada anak dengan usia yang lebih muda ( $<2$ tahun). ${ }^{20,21,24}$ Penelitian di Turki, mendapatkan $8 \%$ kasus pneumonia pada infeksi influenza. Pada penelitian tersebut, sebagian besar subjek yang mengalami infeksi influenza berusia $<5$ tahun dan influenza A merupakan infeksi terbanyak. ${ }^{20}$ Pada penelitian ini tidak didapatkan kasus infeksi influenza pada subjek yang didiagnosis 
pneumonia. Hal tersebut disebabkan karena sebagian besar infeksi influenza didapatkan pada usia $>5$ tahun dan infeksi influenza B yang memberikan gejala lebih ringan yang lebih banyak ditemukan. Namun, juga perlu dipertimbangkan bahwa proporsi subjek dengan pneumonia hanya 9,6\% dari keseluruhan sampel penelitian.

Penelitian ini mendapatkan 8,3\% proporsi infeksi influenza pada anak dengan ILI atau pneumonia, terutama influenza B. Usia merupakan faktor yang berperan dalam infeksi influenza. Karakteristik klinis subjek dengan infeksi influenza sesuai dengan manifestasi klasik penyakit tersebut.

\section{Daftar pustaka}

1. Kieny MP, Girard MP. Human vaccine research and development: an overview. Vaccine 2005;23:5705-7.

2. Mizgerd JP. Lung infection-a public health priority. Plos Med 2006;3: e76.

3. WHO (world health organization), Februari 2009. Acute respiratory infection.

4. (Diakses tanggal 4 Agustus 2014). Diunduh dari: http:// www.who.int/vaccine_research/diseaselarilen/index.html.

5. Grijalva CG, Poehling KA, Edwards KM, Weinberg GA, Staat MA, Iwane MK, dkk. Accuracy and interpretation of rapid influenza test in children. Pediatrics 2007;119: e6-e11.

6. Grijalva CG, Craig AS, Dupont WD, Bridges CB, Schrag SJ, Iwane MK, dkk. Estimating influenza hospitalizations among children. Emerg Infect Dis 2006;12:103-9.

7. Musher DM. How contagious are common respiratory tract infections? N. Eng. J. Med 2003;348:1256-66.

8. Ruest A, Michaud S, Deslandes S, Frost EH. Comparison of the direct antigen flu $\mathrm{A}+\mathrm{B}$ test, the quick vue influenza test and clinical case definition to viral culture and reverse transcription PCR for rapid diagnosis of influenza virus infection. J Clin Microbiol 2003;41:3487-93.

9. Bolvin G, Hardy I, Tellier G, Maziade J. Predicting influenza infections during epidemics with use of a clinical case definition. Clin Infect Dis 2000;31:1166-9.

10. Monto AS, Gravenstein S, Elliott M, Colopy M, Schweinle J. Clinical signs and symptoms predicting influenza infection. Arch Intern Med 2000;160:32437.

11. Zambon MC, Stockton JD, Clewley JP, Fleming DM.
Contribution of influenza and respiratory syncytial virus to community cases of influenza-like illness: an observational study. Lancet 2001;358:1410-6.

12. Weinberg GA, Erdman DD, Edwards KM. Superiority of reverse-transcription polymerase chain reaction to conventional viral culture in the diagnosis of acute respiratory tract infections in children. J Infect Dis 2004:706-10.

13. Poehling KA, Griffin MR, Dittus RS. Bedside diagnosis of influenza virus infections in hospitalized children. Pediatrics 2002;110:83-8.

14. Uyeki TM. Influenza diagnosis and treatment in children: a review of studies on clinically useful test and antivira treatment for influenz. Pediatr Infect Dis J 2003;22:164-77.

15. PC Woo, SS Chiu, WH Seto and M Peiris. Costeffectiveness of rapid diagnosis of viral respiratory tract infctions in pediatric patients. J. Clin. Microbiol 1997;35:1579-81.

16. Poehling KA, Zhu Y, Tang YW, Edwards K. Accuracy and impact of a point-of-care rapid influenza test in young childrenwith respiratory illnesses. Arch. Pediatr. Adolesc. Med 2006;160:713-8.

17. CDC 2009. Seasonal influenza (flu) rapid diagnostic testing for influenza. (Diakses tanggal 4 Agustus 2014). Diunduh dari: http://www.cdc.gov/flu/profesionals/diagnosis/ rapidclin.htm.

18. Chartrand C, Leeflang MMG, minion J, Brewer T, Pai M. Accuracy of rapid influenza diagnostic test a metaanalysis. Ann Intern Med 2012;156:500-11.

19. Purniti PS, Subanada IB, Iswari IS. Surveilans influenza pada pasien rawat jalan. Sari. Pediatri 2010;12:27882.

20. Thompson WW, Shay DK, Weintraub E, Brammer L, Cox N, Anderson LJ, dkk. Mortality associated with influenza and respiratory synncytial virus in the united states. JAMA 2003;289:79-86.

21. Peltola V, Ziegler T, Ruuskanen O. Influenza a and b virus infections in children. Clin Infect Dis 2003;36:299305.

22. Coelho MC, Tsuchiya LRRV, Nogueira MB, Pereira L, Takahashi GA, Raboni SM. Impact of respiratory infections by influenza viruses $a$ and $b$ in pediatrics patients from federal university of parana brazil. The Brazilian J Infect Dis 2007;11:220-3.

23. Wonodi CB, Knoll MD, Feikin DR, Deluca AW, Driscoll AJ, Moisi JC. Evaluation of risk factors for severe pneumonia in children: the pneumonia etiology research for child health. Clin Infect Dis 2012;54:124-31. 
24. Rudan I, Boschi-Pinto C, Biloglav Z, Mulholand K, Campbell H. Epidemiology and etiology of childhood pneumonia. Bull World Health Organ 2008;86:40816.
25. Monto AS, Gravenstein S, Elliot M, Colopy M, Schweinle J. Clinical signs and symptoms predicting influenza infection. Arch Intern Med 2000;160:32437. 